Article

\title{
Interpretive Structural Analysis of Interrelationships among the Elements of Characteristic Agriculture Development in Chinese Rural Poverty Alleviation
}

\author{
Yi Cai ${ }^{1,2(\mathbb{D})}$ and Chunping Xia ${ }^{1,2, *}$ \\ 1 College of Economics and Management, Huazhong Agricultural University, Wuhan 430070, China; \\ caiyi@webmail.hzau.edu.cn \\ 2 Hubei Rural Development Research Center, Huazhong Agricultural University, Wuhan 430070, China \\ * Correspondence: xcp@mail.hzau.edu.cn
}

Received: 5 January 2018; Accepted: 10 March 2018; Published: 13 March 2018

\begin{abstract}
Eradicating poverty is a strategic priority in the pursuit of Sustainable Development Goals. This study intends to identify and quantify the elements affecting the Characteristic Agriculture Development (CAD) project implemented in area of Chinese poverty and reveals the interrelationships between those elements. First-hand data for the structural modeling were collected through semi-structured interviews with a group of selected experts. As a result, this study has identified seventeen representative elements, and the interrelationships between them have been examined based on the Interpretive Structural Modeling (ISM) method. Furthermore, these elements were further categorized into four categories depending on their driving power and dependence power by using the cross-impact matrix multiplication applied to classification (MICMAC) analysis. The combination result of the elements identification, ISM modeling and MICMAC analysis provide a conceptual framework for designing, implementing, and managing CAD projects conducted in rural China. Finally, we suggest that an appropriate approach should be applied to empower the poor, promote target group participation, optimize the regional agriculture structure, and increase the agro value chain competiveness in CAD project implementation.
\end{abstract}

Keywords: Characteristic Agriculture Development; poverty alleviation; Interpretive Structural Modeling; rural China

\section{Introduction}

The world we live in today is marked by high technology and abundant commercial goods. However, it is also marked by severe poverty and ever greater inequality [1]. Ever since the reform and opening-up in the late 1980s, China has experienced rapid economic growth accompanied by dramatic reduction in absolute rural poverty [2,3]. The number of rural poor had fallen to 55.75 million and the rural poverty incidence dropped to $5.7 \%$ by 2015 . China made significant contributions to the Millennium Development Goals achievement on halving the extremely poor population. China's commitment to lifting the entire poor population in rural areas out of poverty by 2020 is a crucial step in implementing the UN 2030 agenda for Sustainable Development Goals.

Chinese agriculture reform aims to enhance the efficiency and effectiveness of agriculture sector [4]. As the main strategy to boost rural household's income, agriculture product with regional features is promoted to increase agriculture revenue and reduce rural poverty by the Chinese government [5]. Characteristic industry indicates an industry or sector in which one region has some competitive advantage that can be originated by a variety of factors: e.g., specific technology and social know-how, natural resources, geographic location, ecological pattern, etc. [6,7]. Owing to the fact that most of the Chinese impoverished population live in remote and mountainous 
areas $[8,9]$, poor communities and their members can benefit from taking advantage of regional special resources [10]. In this regard, Characteristic Agriculture Development (CAD) has been introduced and commonly applied in Chinese rural development and poverty reduction. By encouraging eligible farmer to participate into a profitable and sustainable agro value chain, CAD strategy aims to promote poor household's self-accumulation ability and finally help them escape the poverty trap. Furthermore, Community-Driven Development (CDD) approach and Agro Value Chain Development (AVCD) approach have been applied in Chinese CAD projects to promote and secure the benefit of poor households.

Targeting on CAD, this paper identified critical elements in affecting Chinese CAD projects and investigated the interrelationships between those elements. Our study contributes to the literature in two respects. First, it raises the awareness of academics and practitioners on CAD, which is the basic strategy for rural development and poverty reduction around the globe. Second, after identifying a list of key CAD project elements, we further developed linkages among various elements by using Interpretive Structural Modeling (ISM) method and the cross-impact matrix multiplication applied to classification (MICMAC) analysis. Our results provide a unique view to understand Chinese CAD projects. To achieve the research goal, the ISM method is employed to establish a hierarchical structure between the elements, and the MICMAC analysis is used to analyze the driving power and dependence power for each element. The main driver of such an agenda is the belief that effective CAD project design, implementation, and management can be achieved by understanding the complex interrelationships between the critical elements.

\section{Literature Review}

Agriculture development remains the key to rural development and poverty reduction in many developing countries, notably China [3,11,12]. Structural adjustment is one of the important contents of Chinese agricultural reform [4]. According to the Chinese Major Function-Oriented Zoning Policy [13], 357 out of 592 national-level poverty-stricken counties are located in the restricted and forbidden development zones. Ecological and environmental protections are priorities for those areas. A nationwide survey covering 2075 poor households in 13 provinces reveals that poor households' primary income sources are crop planting, animal breeding, and part-time jobs in local areas [8]. Their study also suggests that people who make up the poor population were longing for social security, agriculture development, occupational training, and low interest loans. By using the CDD approach and the AVCD approach, Chinese government conducts CAD projects to explore the regional comparative advantage of poverty areas in agriculture production $[4,8,14]$.

Since the 1990s, governments and international organizations around the world have begun to adopt a participatory approach to execute development projects on capability-building, access to infrastructure, and public services, and reducing economic, social and ecological vulnerabilities [15-18]. As a typical kind of participatory approach, the CDD approach departs from traditional poverty alleviation methods by promoting decentralized rural development, improving project management efficiency, and encouraging participation of the target group [19]. For a certain CDD project, project participants are identified as the most influential elements [20]. Their involvements in project selection, implementation, and monitoring determine the efficiency and effectiveness of the project pro-poor effect $[21,22]$. In order to promote the sustainability of CDD projects, stakeholders should be offered education opportunities to improve their production and management skills [23-26]. Furthermore, because of the fact that native residences are more familiar with local conditions than foreign workers, creating an enabling environment and encouraging community engagement would be beneficial for CDD project implementation $[27,28]$.

Even though CDD approach has been proven as an effective method to revitalize hollowed villages in traditional agricultural areas of China [29], there are still some issues that need to be addressed in the Chinese poverty alleviation sector. Comparing with the poverty reduction projects conducted by NGOs, and research indicates that Chinese government-led CDD projects lack poor households and 
rural community engagements [30]. Evidence from the practice of Chinese poverty alleviation and rural development suggests the existence of pattern of elite capture of rural community resources [31]. This pattern can also be found in international development projects conducted in Sub-Saharan Africa, Indonesia, and Nepal [32-34]. Furthermore, rural out-migration and aging of the population have weakened the strength of collective action among Chinese impoverished communities, especially for the communities where residents are trapped in chronic poverty [35].

Disadvantaged groups can easily benefit from CAD projects in the short- and medium-term, but hardly in the long-term [26,36,37]. It has been commonly found that CAD projects in rural China can hardly sustain themselves without continuous assistance from external sources [38]. The AVCD approach has been applied to improve CAD project sustainability by enhancing regional agriculture competitiveness in rural China [31,39]. Based on the value chain analysis, researchers introduced a theoretical framework for sustainable anti-poverty project design, implementation, and management [40]. Their companion study further proposed a step-by-step approach for upgrading the agro value chain to improve small producers' participation [41]. Agriculture industrialization has been proposed to forge collaborative relationships between major participants in CAD projects [42]. Their study also highlights that project sustainability and the long-term pro-poor effect can be promoted by using production and marketing contracts and vertical integration methods.

Some other critical factors affecting CAD projects can also be found in the existing literature. As it can be learned from the CAD practice in Nicaragua, small producers' livelihood strategies are limited by the lack of initial input assets [43]. A broad empirical study supports the point that political, financial, and social supports from external sources are of great importance to conduct CAD projects successfully [44-46]. In this regard, scholars proposed an asset-based approach for reconstructing and upgrading the value chain to secure the participation of the target group [47]. Moreover, creation of regional identity can add value to local products [48]. Evidence has been found in the value-added vegetable production industry in the poverty-stricken counties near the capital of China [49]. Furthermore, the lack of access to infrastructure and public services in China's remote areas limit farmers' abilities to protect themselves from market failures and natural disasters $[39,50]$.

\section{Methodologies}

The combination results of the ISM method and the MICMAC analysis can provide a clear profile of the interactive relationships among specific elements for certain issues [51]. This approach has already been applied in fields such as the automobile industry [52], the manufacturing industry [53,54], the carbon emission trading system [55], and others. To achieve the aim of this study, the research work has been conducted using the procedures explored below.

\subsection{Element Identification}

The research starts with identifying the representative elements affecting CAD projects in China's poverty-stricken areas. In order to conduct a comprehensive investigation of the elements affecting $\mathrm{CAD}$, the research team conducted content analysis based on a wide range of literature, reports, official documents, and authoritative websites. Authoritative websites utilized include the Web of Science, the China National Knowledge Infrastructure database, the Global Poverty Reduction and Inclusive Growth Portal website, the Global Poverty Reduction Online Knowledge Sharing Database, and the official website of the State Council Leading Group Office of Poverty Alleviation and Development. We then conducted semi-structured interviews with a group of selected experts who have sufficient theoretical knowledge and practical experience on Chinese rural development and poverty alleviation to assist in selecting the representative elements.

\subsection{ISM Method}

The major purpose of this stage is to build a hierarchy structure between the representative elements by employing the ISM method. ISM is an interactive learning process [51]. This technique 
is used to describe complex relationships among a set of different directly- and indirectly-related elements by constructing a carefully designed pattern implying graphics and words [56,57]. Figure 1 illustrates the procedures of applying the ISM method.

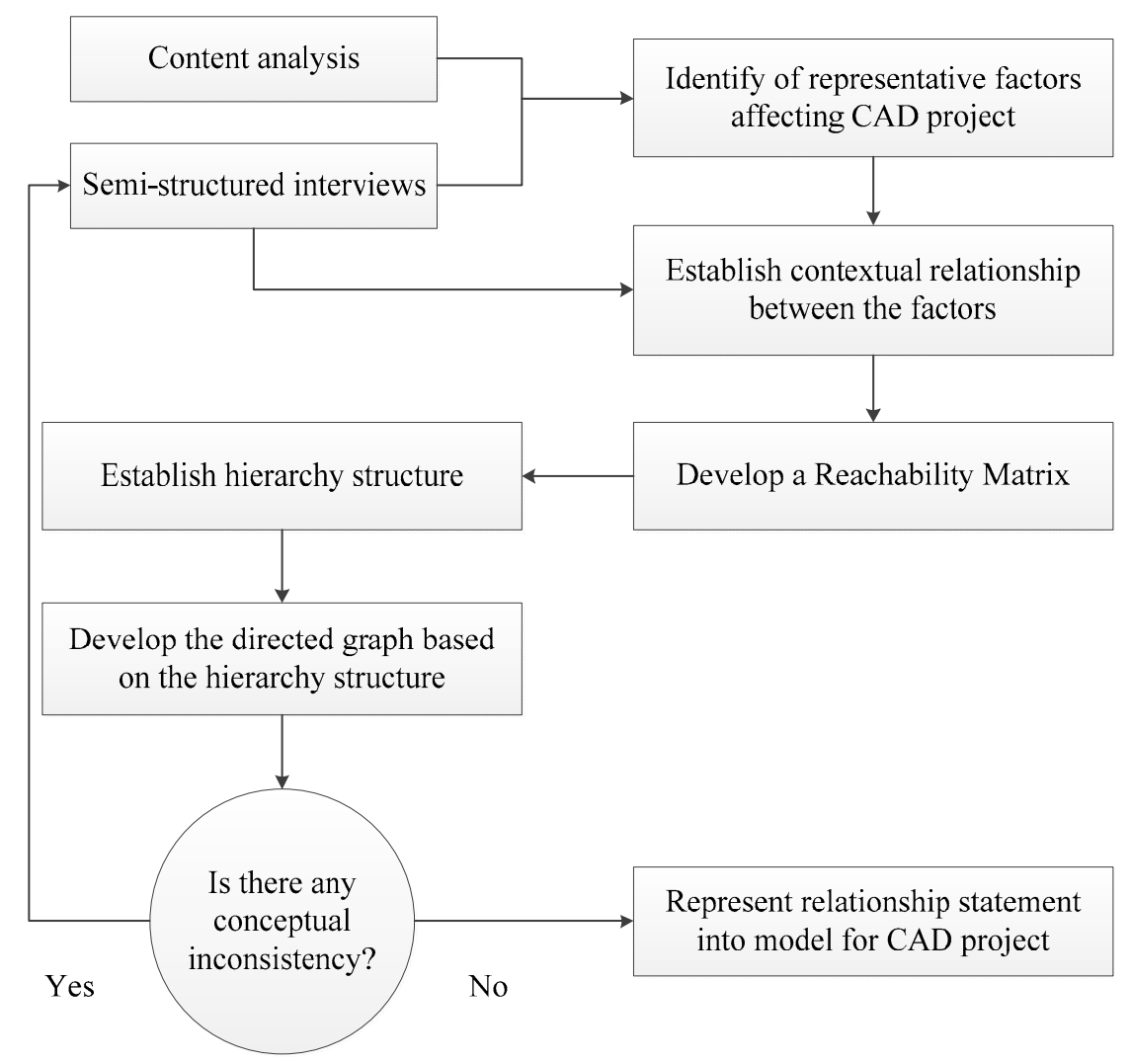

Figure 1. Procedures of applying the ISM method.

There are three main steps to the ISM method. First, identify the representative elements which are relevant to the target issue through content analysis and semi-structured interviews with selected experts. Second, establish a contextual relationship between elements by examining their connection with each other. The contextual relationship can be transfer into an initial reachability matrix, and then further convert into a final reachability matrix. Third, partition the final reachability matrix into different levels and present the results for expert modification. The quality of respondents is much important in ISM method than the quantity of respondents [55]. Hence, the interviewees should have sufficient knowledge of the focal area.

\subsection{MICMAC Anaylsis}

The MICMAC analysis is employed to identify key elements that drive the project by analyzing their drive power and dependence power [58]. The drive power of an element can be obtained by adding up the number of ones in the rows from final reachability matrix. The dependence power is found by summing up the number of ones in the columns. The elements are further classified into four categories based on their driving power and dependence power: driving elements, dependent elements, autonomous elements, and linkage elements [54]. The driving element has strong driving power, but poor dependence power, while the dependent element possesses weak driving power, but strong dependence power. The element with medium driving power and dependence power are classified as the linkage element. The autonomous element represents the element with both weak driving power and dependence power [59]. 


\section{The Implementation of CAD in Rural China}

In 2014, the Chinese government introduced the Accurate Targeting Poverty Alleviation Mechanism to further increase the efficiency of rural poverty reduction project. This mechanism highlights accurate poverty identification, appropriate project arrangement, and scientific implementation to ensure that the resource and assistance are delivered directly to poverty-stricken villages and households [8].

Following the Accurate Targeting Poverty Alleviation Mechanism, the CAD project begins with impoverished household identification. Employing its political and institutional advantages, the Chinese government selected and assigned grassroots-level officials, local officers from relevant governmental line agencies, and cadres selected from superior administrations, public institutions, universities, organizations, and state-owned enterprises to join the Poverty Alleviation Task Force (PATF). Their mission is to help poor villages and impoverished households out of poverty. PATF identifies poor households under procedures of the Accurate Targeting Poverty Alleviation Mechanism. Next, PATF tries to grant poor households access to remunerative technologies, high-return assets, and livelihood strategies by diagnosing the major issues of all of them. In addition to farmers and PATF, a New Agriculture Management Entity (NAME) is also a participant of the CAD project. The NAME includes large-scale farmers, farmer cooperatives, and agriculture enterprises. They receive preferential policies from local governments and bear the responsibility to secure the interest of poor households from agro value chain participation. For example, poor farmers are encouraged to cooperate with agriculture enterprises by pooling their lands and then drawing dividends on land shares. In the meantime, these farmers are also employed by the NAME to collect a stable income (e.g., farming, grading, bulking up, and transporting). Additionally, low interest loans have been provided for impoverished farmers to initiate production jointly guaranteed by the local government and the NAME.

A well-operated CAD project can not only expand the local agricultural business scale, but also increase local fiscal revenue. While promoting its own growth, the NAME pays more tax to the local government. An expanding tax base and an increasing tax revenue allows local governments to provide better public services and implement a regional marketing strategy (i.e., regional identity creation). CAD will thus become more inclusive by creating diverse jobs and benefiting poor households in a broader area.

\section{Selection of Representative Elements}

Semi-structured interviews with PATF members were organized to further summarize and select the representative elements. The research team conducted surveys in the Guangxi Zhuang Autonomous Region and Hubei Province from January to August 2017. As shown in Table 1, the team interviewed the PATF members and poor households who participated in the navel orange industry in Jingxi City, the mango industry in Tianyang County, and Tiandong County, the mushroom industry in Nanzhang County, the kiwi industry in Jianshi County, the nursery stock industry in Xiaochang County, and the vegetable industry in Macheng City.

Table 1. Investigated areas and CAD project.

\begin{tabular}{|c|c|c|}
\hline Province & City/County & CAD Project \\
\hline \multirow{3}{*}{ Guangxi Zhuang Autonomous Region } & Jingxi City & Navel orange industry \\
\hline & Tianyang County & \multirow[t]{2}{*}{ Mango industry } \\
\hline & Tiandong County & \\
\hline \multirow{4}{*}{ Hubei province } & Nanzhang County & Mushroom industry \\
\hline & Jianshi County & Kiwi industry \\
\hline & Xiaochang County & Nursery stock industry \\
\hline & Macheng City & Vegetable industry \\
\hline
\end{tabular}


As a result, the above efforts led to discussions with 68 PATF members. However, it was found that 45 of these 68 interviewees had sufficient knowledge of, and experience in, rural development and poverty alleviation. In the end, the research team managed to obtain support from 35 of these experts for in-depth interviews. As it is shown in Table 2, average working duration in rural development and poverty alleviation of the selected experts from all age groups is at least two years. Their opinions are effective for the ISM modeling and the MICMAC analysis in this research.

Table 2. Expert's working duration in rural development and poverty alleviation.

\begin{tabular}{cccc}
\hline Number & Age & $\begin{array}{c}\text { Average Duration in Rural } \\
\text { Development (Year) }\end{array}$ & $\begin{array}{c}\text { Average Duration in } \\
\text { Poverty Alleviation (Year) }\end{array}$ \\
\hline 7 & $20-35$ & 5.7 & 2.4 \\
18 & $35-50$ & 14.5 & 5.8 \\
10 & More than 50 & 23.2 & 7.3 \\
\hline \multicolumn{3}{c}{ Occupation } & Number \\
\hline & Local officers & 14 \\
& Village cadres & \multicolumn{2}{c}{6} \\
\hline
\end{tabular}

The research team has carefully analyzed feedback information and made necessary corrections based upon interviewee responses. A summary of the elements and their definitions are shown in Table 3.

Table 3. Representative elements and definitions.

\begin{tabular}{ll}
\hline Elements & Definition \\
\hline E1-Project sustainability & CAD project economic, social, and environmental sustainability \\
\hline E2-Capacity building & Improving participant's ability on decision-making, production, management, marketing, etc. \\
\hline E3-Coverage scope & CAD project's beneficiary groups and regions \\
\hline E4-Market development & Small business operators' access to more stable, bigger or higher-value markets \\
\hline E5-Regional identity creation & Placed-based marketing strategy for advertising the local distinct agricultural products \\
\hline E6-Project management & Target group identification, project supervision, and evaluation \\
\hline E7-Information and logistics system & Rural transport and ICT infrastructure \\
\hline E8-Operation mechanism & Contractual relationships between poor households and the NAME \\
\hline E9-Productivity & Farmer's productivity under certain production standards \\
\hline E10-Farming scale & The area of land used to participate in the CAD project by the farmer \\
\hline E11-Cooperation between farmers & Collaborative production and mutual aid between farmers within the rural community \\
\hline E12-Project selection & Stakeholders' agreement on certain CAD project proposals \\
\hline E13-Support system & Financial, medical, and agriculture insurance support for the CAD project and its participants \\
\hline E14-Farmer & CAD project participants \\
\hline E15-NAME & CAD project participants, including large-scale farmers, farmer cooperatives, and agriculture enterprises \\
\hline E16-Location & Local natural, geographical, and cultural conditions \\
\hline E17-PATF & CAD project participant, consisting of grassroots-level officials, local officers, cadres, etc. \\
\hline &
\end{tabular}

As a result, the team identified farmers (E14), NAME (E15), and PATF (E17) as participants of the CAD project. Before project initiation, the roles and responsibilities of the NAME and PATF should be specifically defined and agreed on by the participants. Experts from the vegetable industry in Macheng city pointed out that the PATF is essential for the launch of the project because they are in charge of the poor household identification. The engagement of the PATF throughout entire project lifecycle is critical for a successful project implementation. Farmers and the NAME are the main producers in the CAD project. Their engagement directly exerts an influence on the CAD project sustainability. Financial and medical support systems in rural China have been upgraded to secure rural development and poverty alleviation. In this regard, stakeholder's capacity (E3), project management (E6), cooperation between farmers (E11), project selection (E12), and support systems (E13) are summarized from the perspective of CDD approach. 
In a specific CAD project, natural, geographical, and cultural conditions limit the choice of remunerative crops and farming operations [60]. Basic strategies for upgrading the agro value chain are: focusing on the stages of production (e.g., delivering larger volumes and matching higher standard), processing (e.g., invoicing, reducing wastage), transport (e.g., building cool chain, employing air freight), and marketing (e.g., advertising, developing local food brand) [61-65]. Linking farmers and the NAME through contract farming is considered as a possible method to secure value chain participation [66]. Collective action among producers on procedures, including standard production, deep processing, and regional marketing, can increase revenue and mitigate individual risks. From the regional perspective, it is also the precondition for developing regional identity. However, concerns on the ecological and environmental sustainability arise from the increase of mono-cropping and the waste of natural resources [31]. The conflicts between economic rewards and rural sustainability should be taken into consideration in project's ex ante evaluation, especially for those areas located in restricted and forbidden development zones of China where the priority is ecological and environmental protection. Attention should also be paid to the changing local social arrangements and labor relations within the implementation stage [67].

A well-developed CAD project will create diverse employment opportunities. Opportunities for women and the disabled emerge for grading, bulking produce for sale, and operating e-commerce when the agricultural industry development reaches a certain level. Cases of this are in Tiandong County and Tianyang County, located in the Youjiang River Valley area, which is one of the largest mango industry bases in China with a long history of mango production. Since 1985, the local government has promoted the mango industry as one of the pillar industries to accelerate rural poverty eradication. By the end of December 2016, the size of the mango industry had surpassed 120.76 million $\mathrm{mu}(1 \mathrm{mu}=0.0667$ hectares), with over 46.82 million tons of mango produced, and a total output value exceeding 28.79 million yuan (approximately 4.5 million USD). The increasing awareness of regional mango production has led to the area being called 'Home of Chinese mango'. This regional identity benefits small producers to a large extent. In 2016, nearly $10 \%$ of mangos were sold through the large e-commerce platforms (e.g., Taobao, Jingdong) and personal e-commerce platform (e.g., Wechat). Experts from Tianyang County have suggested that encouraging eligible poor households to participate in the mango industry is the best choice for poverty reduction in neighborhood areas. At this time, poor farmers could earn enough to be over the poverty line by cultivating $1 \mathrm{mu}$ of mango orchard ( 2016 poverty line $=3000$ yuan, approximately $\$ 462$ USD). This growing industry also provides more opportunities for women and the disabled in areas such as product classification and assistance in managing online transactions. In this regard, we identified project sustainability (E1), coverage scope (E2), market development (E4), regional identity creation (E5), information and logistics system (E7), operation mechanism (E8), productivity (E9), farming scale (E10), and location (E16).

\section{Model and Results Analysis}

In this section, the ISM method is applied to establish a hierarchal structure between the 17 representative elements. Moreover, the MICMAC analysis is employed to classify the elements based upon their driving-power and dependence-power. The application of the ISM method and the MICMAC analysis is described below.

\subsection{Reachability Matrix}

We translated expert's opinions on the contextual relationships between the identified elements into a binary digit matrix called initial reachability matrix [55]. In the interview, experts responded to question "Do you think element $i$ directly affects element $j$ " to conduct a pairwise comparison of the elements. The contextual relationships can, thus, be created. The final results from the experts' opinions are based on the principle of "the minority gives way to the majority" since different experts may have different views on the interrelationship between two elements. We then marked 1 on $(i, j)$ in the initial reachability matrix if element $i$ has a direct influence on element $j$. The final result of contextual 
relationships between the 17 representative elements has been translated in initial reachability matrix in Table 4.

Table 4. The initial reachability matrix between 17 representative elements.

\begin{tabular}{llllllllllllllllll}
\hline & E1 & E2 & E3 & E4 & E5 & E6 & E7 & E8 & E9 & E10 & E11 & E12 & E13 & E14 & E15 & E16 & E17 \\
\hline E1 & & & & & & & & & & & & & & & & & \\
E2 & 1 & & & 1 & & & & & & & & & & & & & \\
E3 & 1 & & & & & & & & & & & & & & & \\
E4 & 1 & & & & & & & & & & & & & & & \\
E5 & 1 & & & & & & & & & & & & & & & \\
E6 & & & & 1 & 1 & & & & & & & & & & & \\
E7 & & & & 1 & & 1 & & & & & & & & & & & \\
E8 & & 1 & 1 & & 1 & 1 & & & 1 & 1 & & & & & & & \\
E9 & & & & & & 1 & & & & 1 & & & & & & & \\
E10 & & & & & & 1 & & 1 & 1 & & & & & & & \\
E11 & & 1 & 1 & & 1 & & & 1 & 1 & 1 & & & & & & \\
E12 & 1 & 1 & 1 & 1 & 1 & & & 1 & & & & & & & & \\
E13 & & 1 & 1 & 1 & & & & 1 & & 1 & 1 & & & 1 & 1 & & \\
E14 & & 1 & 1 & & & & & 1 & 1 & 1 & 1 & & & & & & \\
E15 & & 1 & 1 & & & & & 1 & 1 & 1 & & & & & & & \\
E16 & & & 1 & & 1 & & 1 & 1 & & 1 & & 1 & & & & & \\
E17 & & 1 & 1 & 1 & 1 & & 1 & 1 & & & & 1 & 1 & & 1 & & \\
\hline
\end{tabular}

In order to reveal the indirect relationships among these 17 representative elements, we further converted the initial reachability matrix into a final reachability matrix based on transitivity principle [51]. The final reachability matrix is produced by conducting power iteration analysis based on the initial reachability matrix, which can tell both element $i$ 's direct $[(i, j)=1]$ and indirect $[(i, j)=2]$ influence on element $j$. Moreover, considering the fact that each element has impact on its own, we enter $[(i, i)=1]$ into the diagonal line of the final reachability matrix. As a result, the final reachability matrix is obtained and shown in Table 5.

Table 5. The final reachability matrix between 17 representative elements.

\begin{tabular}{|c|c|c|c|c|c|c|c|c|c|c|c|c|c|c|c|c|c|}
\hline & E1 & E2 & E3 & E4 & E5 & E6 & E7 & E8 & E9 & E10 & E11 & E12 & E13 & E14 & E15 & E16 & E17 \\
\hline E1 & 1 & & & & & & & & & & & & & & & & \\
\hline E2 & 1 & 1 & & 1 & & & & & & & & & & & & & \\
\hline E3 & 1 & & 1 & & & & & & & & & & & & & & \\
\hline E4 & 1 & & & 1 & & & & & & & & & & & & & \\
\hline E5 & 1 & & & & 1 & & & & & & & & & & & & \\
\hline E6 & 2 & & & 1 & 1 & 1 & & & & & & & & & & & \\
\hline E7 & 2 & & & 1 & 2 & 1 & 1 & & & & & & & & & & \\
\hline E8 & 2 & 1 & 1 & 2 & 1 & 1 & & 1 & 1 & 1 & & & & & & & \\
\hline E9 & 2 & 2 & 2 & 2 & 2 & 1 & & 2 & 1 & 1 & & & & & & & \\
\hline E10 & 2 & 2 & 2 & 2 & 2 & 1 & & 1 & 1 & 1 & & & & & & & \\
\hline E11 & 2 & 1 & 1 & 2 & 1 & 2 & & 1 & 1 & 1 & 1 & & & & & & \\
\hline E12 & 1 & 1 & 1 & 1 & 1 & 2 & & 1 & 2 & 2 & & 1 & & & & & \\
\hline E13 & 2 & 1 & 1 & 1 & 2 & 2 & & 1 & 2 & 1 & 1 & & 1 & 1 & 1 & & \\
\hline E14 & 2 & 1 & 1 & 2 & 2 & 2 & & 1 & 1 & 1 & 1 & & & 1 & & & \\
\hline E15 & 2 & 1 & 1 & 2 & 2 & 2 & & 1 & 1 & 1 & & & & & 1 & & \\
\hline E16 & 2 & 2 & 1 & 2 & 1 & 2 & 1 & 1 & 2 & 1 & & 1 & & & & 1 & \\
\hline E17 & 2 & 1 & 1 & 1 & 1 & 2 & 1 & 1 & 2 & 2 & 2 & 1 & 1 & 2 & 1 & & 1 \\
\hline
\end{tabular}

\subsection{Level Partition}

The element's reachability set and antecedent set are derived from the final reachability matrix. The element's reachability set is composed of the element itself and the other elements it directly or indirectly helps achieve, whereas the antecedent set consists of the element itself and the other elements which directly or indirectly help in achieving them [51]. The intersection set includes the 
elements that appear in the reachability set and the antecedent set in the same partitioning period. The element for which the reachability and the intersection sets are the same occupies the bottom level in the ISM hierarchy. Bottom level elements will be discarded from the remaining elements in the next partitioning period. This process is repeated until all the elements' levels are identified [53]. For example, as it is shown in Table 6, E1's reachability set and intersection set include the same element (E1) in the level I partition. In this case, E1 is classified as a bottom level element in the ISM hierarchy and has been removed from the level II partition in Table 7. Information related to the procedures of level partition is shown in Appendix A.

Table 6. Level I partition.

\begin{tabular}{|c|c|c|c|c|}
\hline Element & Reachability Set & Antecedent Set & Intersection Set & Level \\
\hline E1 & E1 & E1, E2, E3, E4, E5, E12, E16, E17 & E1 & I \\
\hline E2 & $\mathrm{E} 1, \mathrm{E} 2, \mathrm{E} 4$ & E2, E8, E9, E10, E11, E12, E13, E14, E15, E16, E17 & E2 & \\
\hline E3 & E1, E3 & E3, E8, E9, E10, E11, E12, E13, E14, E15, E16, E17 & E3 & \\
\hline E4 & $\mathrm{E} 1, \mathrm{E} 4$ & E2, E4, E6, E7, E8, E9, E10, E11, E12, E13, E14, E15, E16, E17 & E4 & \\
\hline E5 & E1, E5 & E5, E6, E7, E8, E9, E10, E11, E12, E13, E14, E15, E16, E17 & E5 & \\
\hline$\vdots$ & $\vdots$ & $\vdots$ & $\vdots$ & \\
\hline E17 & $\begin{array}{l}\text { E1, E2, E3, E4, E5, E6, E7, E8, E9, E10, } \\
\text { E11, E12 E13, E14, E15, E17 }\end{array}$ & E17 & E17 & \\
\hline
\end{tabular}

Table 7. Level II partition.

\begin{tabular}{clcc}
\hline \multicolumn{1}{c}{ Reachability Set } & \multicolumn{1}{c}{ Antecedent Set } & Intersection Set & Level \\
\hline E2 & E2, E4 & E2, E8, E9, E10, E11, E12, E13, E14, E15, E16, E17 & E2 \\
E3 & E3 & E3, E8, E9, E10, E11, E12, E13, E14, E15, E16, E17 & E3 \\
E4 & E4 & E2, E4, E6, E7, E8, E9, E10, E11, E12, E13, E14, E15, E16, E17 & II \\
E5 & E5 & E5, E6, E7, E8, E9, E10, E11, E12, E13, E14, E15, E16, E17 & E5 \\
$\vdots$ & & & $\vdots$ \\
E17 & E2, E3, E4, E5, E6, E7, E8, E9, E10, E11, & E17 & II \\
& E12, E13, E14, E15, E17 & & E17 \\
\hline
\end{tabular}

Based on the level partition results, we generate an ISM-based hierarchy structure between the 17 elements as shown in Figure 2.

As a result, the ISM method classified the 17 elements into eight levels (see Figure 2). Elements including E1 (project sustainability), E2 (capacity building), E3 (coverage scope), E4 (market development), E5 (regional identity creation), and E6 (project management) are at the bottom three levels (I-III) of the ISM hierarchy. It indicates that these six elements are highly dependent on other elements. There are four elements in the top three levels (VI-VIII). E13 (support system), E14 (farmer), E16 (location), and E17 (PATF) are the most essential elements affecting the successful implementation and sustainable development of CAD projects in rural China. In other words, achieving high efficiency and effectiveness performance by the project manager in addressing these four elements will benefit rural communities and poor households to a large extent. Elements positioned in inter-medium level (IV-V) are E7 (information and logistics system), E8 (operation mechanism), E9 (productivity), E10 (farming scale), E11 (cooperation between farmers), E12 (project selection), and E15 (NAME). They are affected by the top level elements and will, in turn, exert an influence on the bottom level elements. Additionally, there are interactions between elements E8 (operation mechanism), E9 (productivity), and E10 (farming scale) at level IV. 


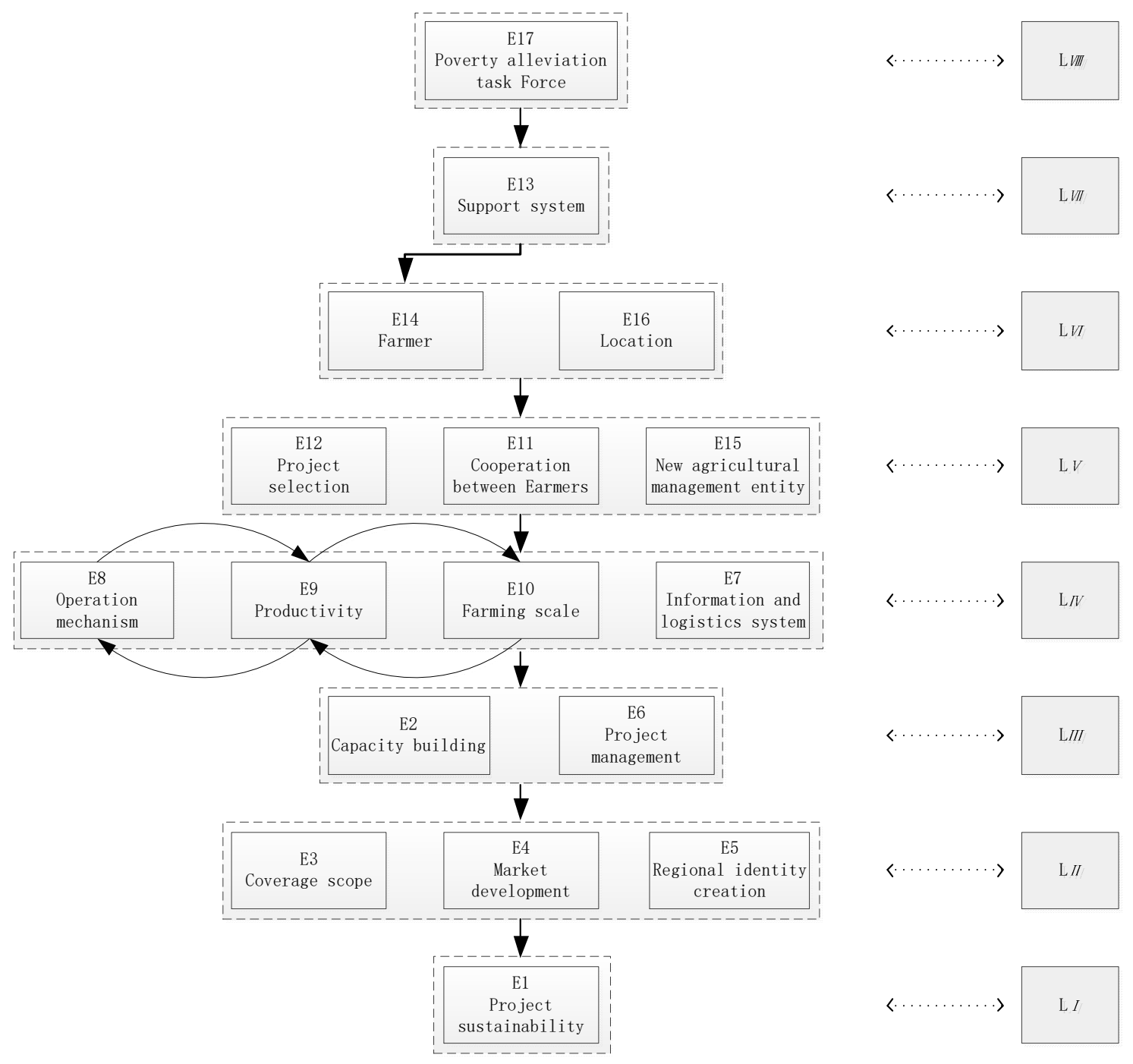

Figure 2. The hierarchy structure of the 17 representative elements.

\subsection{Element Classification}

The MICMAC analysis has been applied to further investigate the elements. The research team calculated the driving power and dependence power based on the information in the final reachability matrix (Table 5). As a result, the team have classified the elements into four categories and derived a two-dimensional diagram, as shown in Figure 3.

- Driving elements: These elements possess strong driving power, but poor dependence power, including E11 (cooperation between farmers), E12 (project selection), E13 (support system), E14 (farmer), E15 (NAME), E16 (location), and E17 (PATF).

- Dependent elements: These elements are found to be clustered in the second quadrant, which have weak driving power, but strong dependence power, including E1 (project sustainability), E2 (capacity building), E3 (coverage scope), E4 (market development), E5 (regional identity creation), and E6 (project management).

- Linkage elements: These elements have medium driving power and dependence power, including E8 (operation mechanism), E9 (productivity), and E10 (farming scale).

- Autonomous elements: These elements have both weak driving power and dependence power. In our study, E7 (information and logistics system) is relatively disconnected from the CAD project as there are only few links to it. 


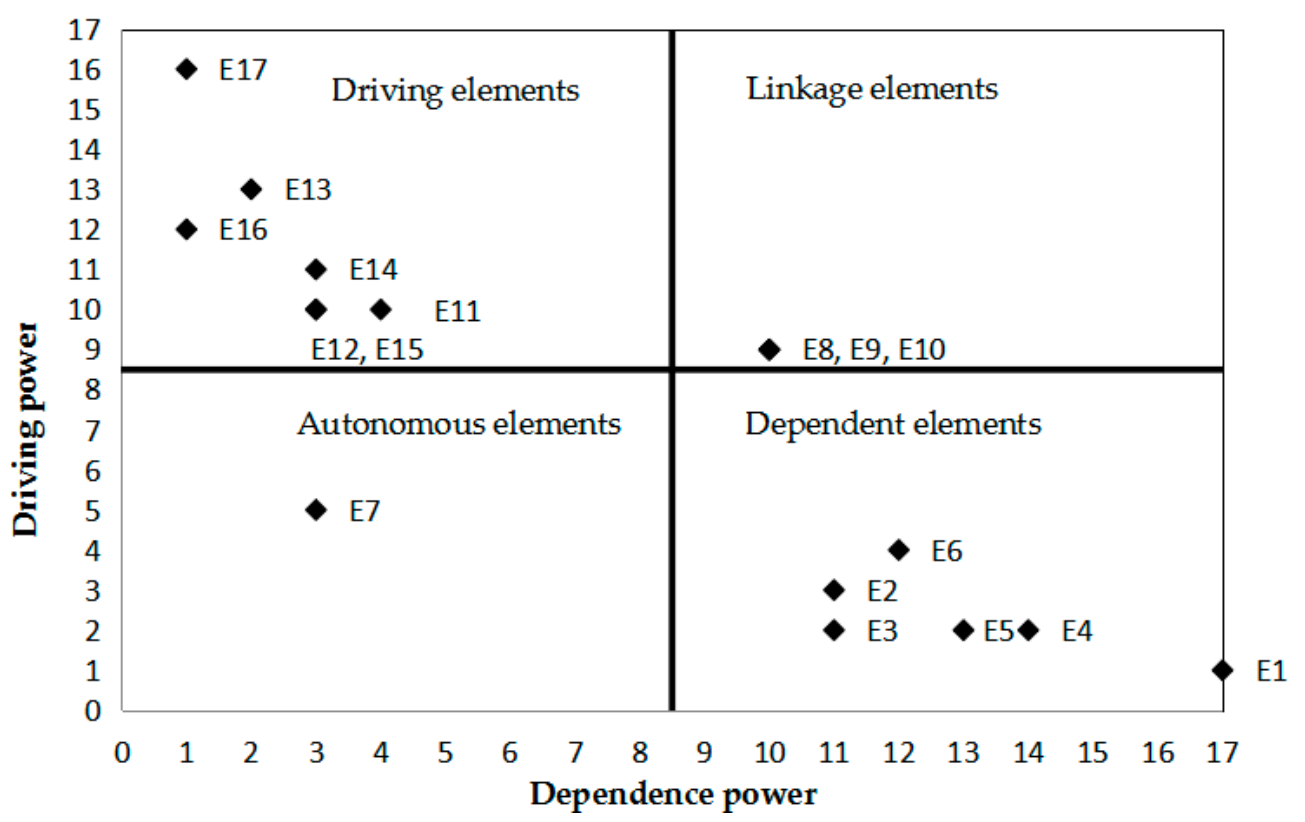

Figure 3. Elements' driving power and dependence power.

\subsection{Result Analysis}

As it can be drawn from the charts above, elements situated on the top three levels in the ISM hierarchy are also located in the first quadrant of the MICMAC analysis output (see Figures 2 and 3). It suggests that these elements deserve more attention due to the fact that they can affect the other elements directly or indirectly. In particular, E17 (PATF) should be given top priority as it lies at the top of the hierarchy and has the strongest driving power. Eradicating rural poverty has always been the greatest concern for both Chinese central and local governments. In order to achieve 'good governance', the government is responsible for making pro-poor policies, upgrading poverty identification and monitoring systems, and building up a comprehensive safeguard system to increase poor households' anti-risk and self-accumulation capability [42]. Selected by the government, the PATF is in charge of eligible farmer identification, project implementation, forging collaborative relationships between participants, and improving institutional and infrastructure conditions. Their administrative capacity, knowledge background, good attitudes, and commitments to poverty reduction are crucial to deal with such time-pressing and task-heavy missions [27,31].

Other driving elements, including E11 (cooperation between farmers), E12 (project selection), E13 (support system), E14 (farmer), E15 (NAME), and E16 (location), are located at the VI-VIII levels in the hierarchal structure. They have strong driving power, but weak dependence power, which means that these elements are more capable of influencing other elements from lower levels. A well-laid plan should consider the conflicts between benefits and risks from a broader perspective [41]. Cooperation between farmers, the NAME, and local officers contributes to social capital accumulation within the rural community, which could enhance collective actions on adopting technology, monitoring product standards, and joint marketing $[68,69]$. In the meantime, the farmer's collective action would also promote the effectiveness of implementation of rural development policies [25,70]. Since the ecological and environmental conditions are relatively vulnerable in chronic poverty areas, institutional supports, such as eco-compensation, labor training, and inclusive healthcare should be imposed in impoverished areas $[50,71]$.

Linkage elements, including E8 (operation mechanism), E9 (productivity), and E10 (farming scale), are sensitive elements due to the fact that any action on these elements will have effects on the dependence elements. There is also a feedback effect on them since they are interrelated. These three elements are positioned at the inter-medium part (IV level) of the ISM hierarchal structure. 
Contracting farming is the most popular agro value chain integration strategy in implementing CAD projects. It regulates the production standard and, thus, interacts with participant's productivity and farming scale.

According to the analysis results from the ISM method and the MICMAC analysis, project sustainability (E1) has the strongest dependence power and is influenced (directly or indirectly) by all of the other elements. E2 (capacity building), E3 (coverage scope), E4 (market development), E5 (regional identity creation), and E6 (project management) are also categorized as the dependent elements and they are placed on the bottom levels of the ISM hierarchy. If the linkage elements, like E8 (operation mechanism), E9 (productivity), and E10 (farming scale), can be well-addressed, it would provide reliable foundations for further building regional reputation and promote the project's coverage scope and, thus, improve the economic and environmental sustainability of the CAD project.

The information and logistics system (E7) is the autonomous element identified in this study. In the survey we found that poor infrastructure conditions in the remote areas limit trading, marketing, and other critical activities for CAD. In recent years, the boost of e-commerce in rural China bridges the digital gap between urban and rural areas. Rural information and communication technology development empowers rural community members and promotes the connection between rural households and the larger market [72]. E-commerce will play an increasingly important role in rural development and poverty reduction in the future [73-75].

\section{Conclusions and Implications}

People who are still left behind may suffer from situations, such as a combination of geographic barriers, cognitive and physical limitations, and market failures [76]. This paper has highlighted 17 representative elements hindering Chinese $\mathrm{CAD}$ projects that pose considerable challenges both for stakeholders and policymakers. By putting the elements into an ISM model, we obtained a hierarchy to demonstrate the interactions between them. The representative elements are further classified into four clusters in a two-dimensional (driving power/dependence power) diagram by applying the MICMAC analysis. The ISM-based model provides great value to the decision-makers by imposing order and direction on the complexity of interrelationships among elements affecting CAD projects.

Even though the CDD approach and the AVCD approach have different foci, they share the same foundation (e.g., participants, natural and geographical conditions, public infrastructure). The CDD approach treats poverty reduction as a management problem [19]. It empowers the target group to manage all aspects of the CAD project, including project selection, management, supervision, and evaluation. Active community engagement increases the poverty alleviation effect by promoting project efficiency and by ensuring poor households' revenue security. The AVCD approach, however, prioritizes problems to address value-chain involvement (e.g., poverty, gender, the disabled) and conflicts between economic development and environmental protection. It enhances agro value chain competiveness by building contractual relationships between poor farmers and NAME, promoting standard production and regional marketing. Both of the approaches enlarge the project's coverage scope and promote the sustainability of CAD project.

The ISM hierarchy and the MICMAC result further reveal the interrelationships between the representative elements. Since the success of each phase carries over to the following phase, project organizers should pay more attention to the elements in the top levels. Previous research has demonstrated that aids from external sources have great importance on poverty alleviation project initiation and management $[38,45,77]$. Our results support this opinion and further suggest that, for CAD projects conducted in Chinese rural areas, PATF should go through strict screening on their recruitment with regard to theoretical knowledge and practical experience on rural development and poverty alleviation. CAD projects should also be carried out in a democratic and environmentally responsible manner based on local conditions and with the support from microfinance, healthcare, and agricultural insurance. Moreover, production and operations management training should be offered to $\mathrm{CAD}$ project participants during and after the project lifecycle. 
Evidence from China, and around the globe, implies that regional identity can add value to local products and industries, such as rural tourism, may benefit from it as well. Our study indicates that a positive regional reputation can be built and, in turn, benefit local industry and community when a CAD project is well developed using the CDD approach and the AVCD approach. Moreover, the growing local economy increases local revenue, which allows the local government to improve public services and invest more on rural infrastructure. A virtuous cycle of rural industrial development can thus be achieved.

Despite the fact that element identification and their interrelationships vary from projects implemented in different scenarios (e.g., nation, leading organization, and economic and social environments), and that the ISM model developed in this research is for the elements identified in CAD projects within the context of China, some generalization of the results is still valuable for rural development and poverty alleviation programs in other countries. When targeting a specific area, an appropriate approach should be applied to empower the poor, promote target group participation, optimize rural agriculture structure, and increase agro value chain competiveness. If problems related to the elements and their interrelationships can be well-addressed, CAD projects will be expected to play a vital role in rural revitalization.

Acknowledgments: The authors would like to thank Scott Loveridge, Yonggong Liu, John Mann, and Kyle Michael Jones for the contributions and comments, as well as the reviewers and editor for their constructive comments. This study was funded by the National Planning Office of Philosophy and Social Science of China (Project No. 17BJY136).

Author Contributions: Yi Cai conducted the study design, prepared datasets, performed the statistical analysis and drafted the manuscript. Chunping Xia organized this study, contributed to study design, interpretation of analysis, and revision of the manuscript.

Conflicts of Interest: The authors declare no conflict of interest.

\section{Appendix A}

Table A1. List of acronyms.

\begin{tabular}{lll}
\hline Characteristic Agriculture Development & CAD & $\begin{array}{l}\text { A poverty alleviation strategy emphasizing on regional } \\
\text { distinct agriculture development. }\end{array}$ \\
\hline Interpretive Structural Modeling & ISM & $\begin{array}{l}\text { ISM method is used to describe complex relationships among } \\
\text { a set of different directly- and indirectly-related elements by } \\
\text { constructing a carefully-designed pattern implying graphics } \\
\text { and words. }\end{array}$ \\
\hline $\begin{array}{l}\text { Cross-impact Matrix Multiplication } \\
\text { Applied to Classification }\end{array}$ & MICMAC & $\begin{array}{l}\text { MICMAC analysis is used to identify the key factors that drive } \\
\text { the system in various categories. }\end{array}$ \\
\hline Community-Driven Development & CDD & $\begin{array}{l}\text { A developmental strategy emphasizes on transparency, } \\
\text { participation, participant empowerment, and greater } \\
\text { downward accountability. }\end{array}$ \\
\hline Poverty Alleviation Task Force & PATF & $\begin{array}{l}\text { CAD project participant, consisting of grassroots-level officials, } \\
\text { local officers, cadres, etc. }\end{array}$ \\
\hline New Agriculture Management Entity & NAME & $\begin{array}{l}\text { CAD project participant, including large-scale farmers, farmer } \\
\text { cooperatives, and agriculture enterprises. }\end{array}$ \\
\hline
\end{tabular}


Table A2. Level I partition.

\begin{tabular}{|c|c|c|c|c|}
\hline Element & Reachability Set & Antecedent Set & Intersection Set & Level \\
\hline E1 & E1 & E1, E2, E3, E4, E5, E12, E16, E17 & E1 & I \\
\hline E2 & $\mathrm{E} 1, \mathrm{E} 2, \mathrm{E} 4$ & $\begin{array}{l}\text { E2, E8, E9, E10, E11, E12, E13, E14, } \\
\text { E15, E16, E17 }\end{array}$ & E2 & \\
\hline E3 & E1, E3 & $\begin{array}{l}\text { E3, E8, E9, E10, E11, E12, E13, E14, } \\
\text { E15, E16, E17 }\end{array}$ & E3 & \\
\hline E4 & $\mathrm{E} 1, \mathrm{E} 4$ & $\begin{array}{l}\text { E2, E4, E6, E7, E8, E9, E10, E11, E12, } \\
\text { E13, E14, E15, E16, E17 }\end{array}$ & E4 & \\
\hline E5 & E1, E5 & $\begin{array}{l}\text { E5, E6, E7, E8, E9, E10, E11, E12, } \\
\text { E13, E14, E15, E16, E17 }\end{array}$ & E5 & \\
\hline E6 & E4, E5, E6 & $\begin{array}{l}\text { E6, E7, E8, E9, E10, E11, E12, E13, } \\
\text { E14, E15, E16, E17 }\end{array}$ & E6 & \\
\hline E7 & E4, E5, E6, E7 & E7, E16, E17 & E7 & \\
\hline E8 & E2, E3, E4, E5, E6, E8, E9, E10 & $\begin{array}{l}\text { E8, E9, E10, E11, E12, E13, E14, E15, } \\
\text { E16, E17 }\end{array}$ & $\mathrm{E} 8, \mathrm{E} 9, \mathrm{E} 10$ & \\
\hline E9 & E2, E3, E4, E5, E6, E8, E9, E10 & $\begin{array}{l}\text { E8, E9, E10, E11, E12, E13, E14, E15, } \\
\text { E16, E17 }\end{array}$ & E8,E9,E10 & \\
\hline E10 & E2, E3, E4, E5, E6, E8, E9, E10 & $\begin{array}{l}\text { E8, E9, E10, E11, E12, E13, E14, E15, } \\
\text { E16, E17 }\end{array}$ & $\mathrm{E} 8, \mathrm{E} 9, \mathrm{E} 10$ & \\
\hline E11 & E2, E3, E4, E5, E6, E8, E9, E10, E11 & E11, E13, E14, E17 & E11 & \\
\hline E12 & E1, E2, E3, E4, E5, E6, E8, E9, E10, E12 & E12, E16, E17 & E12 & \\
\hline E13 & E2, E3, E4, E5, E6, E8, E9, E10, E11, E13, E14, E15 & E13, E17 & E13 & \\
\hline E14 & E2, E3, E4, E5, E6, E8, E9, E10, E11, E14 & E13, E14, E17 & E14 & \\
\hline E15 & E2, E3, E4, E5, E6, E8, E9, E10, E15 & E15, E17 & E15 & \\
\hline E16 & E1, E2, E3, E4, E5, E6, E7, E8, E9, E10, E12, E16 & E16 & E16 & \\
\hline E17 & $\begin{array}{l}\text { E1, E2, E3, E4, E5, E6, E7, E8, E9, E10, E11, E12, } \\
\text { E13, E14, E15, E17 }\end{array}$ & E17 & E17 & \\
\hline
\end{tabular}

Table A3. Level II partition.

\begin{tabular}{|c|c|c|c|c|}
\hline Element & Reachability Set & Antecedent Set & Intersection Set & Level \\
\hline E2 & $\mathrm{E} 2, \mathrm{E} 4$ & $\begin{array}{l}\text { E2, E8, E9, E10, E11, E12, E13, E14, } \\
\text { E15, E16, E17 }\end{array}$ & E2 & \\
\hline E3 & E3 & $\begin{array}{l}\text { E3, E8, E9, E10, E11, E12, E13, E14, } \\
\text { E15, E16, E17 }\end{array}$ & E3 & II \\
\hline E4 & E4 & $\begin{array}{l}\text { E2, E4, E6, E7, E8, E9, E10, E11, E12, } \\
\text { E13, E14, E15, E16, E17 }\end{array}$ & E4 & II \\
\hline E5 & E5 & $\begin{array}{l}\text { E5, E6, E7, E8, E9, E10, E11, E12, } \\
\text { E13, E14, E15, E16, E17 }\end{array}$ & E5 & II \\
\hline E6 & E4, E5, E6 & $\begin{array}{l}\text { E6, E7, E8, E9, E10, E11, E12, E13, } \\
\text { E14, E15, E16, E17 }\end{array}$ & E6 & \\
\hline E7 & E4, E5, E6, E7 & E7, E16, E17 & E7 & \\
\hline E8 & E2, E3, E4, E5, E6, E8, E9, E10 & $\begin{array}{l}\text { E8, E9, E10, E11, E12, E13, E14, E15, } \\
\text { E16, E17 }\end{array}$ & $\mathrm{E} 8, \mathrm{E} 9, \mathrm{E} 10$ & \\
\hline E9 & E2, E3, E4, E5, E6, E8, E9, E10 & $\begin{array}{l}\text { E8, E9, E10, E11, E12, E13, E14, E15, } \\
\text { E16, E17 }\end{array}$ & $\mathrm{E} 8, \mathrm{E} 9, \mathrm{E} 10$ & \\
\hline E10 & E2, E3, E4, E5, E6, E8, E9, E10 & $\begin{array}{l}\text { E8, E9, E10, E11, E12, E13, E14, E15, } \\
\text { E16, E17 }\end{array}$ & E8,E9,E10 & \\
\hline E11 & E2, E3, E4, E5, E6, E8, E9, E10, E11 & E11, E13, E14, E17 & E11 & \\
\hline E12 & E2, E3, E4, E5, E6, E8, E9, E10, E12 & E12, E16, E17 & E12 & \\
\hline E13 & E2, E3, E4, E5, E6, E8, E9, E10, E11, E13, E14, E15 & E13, E17 & E13 & \\
\hline E14 & E2, E3, E4, E5, E6, E8, E9, E10, E11, E14 & E13, E14, E17 & E14 & \\
\hline E15 & E2, E3, E4, E5, E6, E8, E9, E10, E15 & E15, E17 & E15 & \\
\hline E16 & E2, E3, E4, E5, E6, E7, E8, E9, E10, E12, E16 & E16 & E16 & \\
\hline E17 & $\begin{array}{l}\text { E2, E3, E4, E5, E6, E7, E8, E9, E10, E11, E12, E13, } \\
\text { E14, E15, E17 }\end{array}$ & E17 & E17 & \\
\hline
\end{tabular}


Table A4. Level III partition.

\begin{tabular}{|c|c|c|c|c|}
\hline Element & Reachability Set & Antecedent Set & Intersection Set & Level \\
\hline E2 & E2 & $\begin{array}{l}\text { E2, E8, E9, E10, E11, E12, E13, E14, } \\
\text { E15, E16, E17 }\end{array}$ & E2 & III \\
\hline E6 & E6 & $\begin{array}{l}\text { E6, E7, E8, E9, E10, E11, E12, E13, } \\
\text { E14, E15, E16, E17 }\end{array}$ & E6 & III \\
\hline E7 & E6, E7 & E7, E16, E17 & & \\
\hline E8 & E2, E6, E8, E9, E10 & $\begin{array}{l}\text { E8, E9, E10, E11, E12, E13, E14, E15, } \\
\text { E16, E17 }\end{array}$ & & \\
\hline E9 & E2, E6, E8, E9, E10 & $\begin{array}{l}\text { E8, E9, E10, E11, E12, E13, E14, E15, } \\
\text { E16, E17 }\end{array}$ & & \\
\hline E10 & E2, E6, E8, E9, E10 & $\begin{array}{l}\text { E8, E9, E10, E11, E12, E13, E14, E15, } \\
\text { E16, E17 }\end{array}$ & & \\
\hline E11 & E2, E6, E8, E9, E10, E11 & E11, E13, E14, E17 & & \\
\hline E12 & E6, E8, E9, E10, E12 & E12, E16, E17 & & \\
\hline E13 & E2, E6, E8, E9, E10, E11, E13, E14, E15 & E13, E17 & & \\
\hline E14 & E2, E6, E8, E9, E10, E11, E14 & E13, E14, E17 & & \\
\hline E15 & E2, E6, E8, E9, E10, E15 & E15, E17 & & \\
\hline E16 & E2, E6, E7, E8, E9, E10, E12, E16 & E16 & & \\
\hline E17 & $\begin{array}{l}\text { E2, E6, E7, E8, E9, E10, E11, E12, E13, E14, E15, } \\
\text { E17 }\end{array}$ & E17 & & \\
\hline
\end{tabular}

Table A5. Level IV partition.

\begin{tabular}{|c|c|c|c|c|}
\hline Element & Reachability Set & Antecedent Set & Intersection Set & Level \\
\hline E7 & E7 & E7, E16, E17 & E7 & IV \\
\hline E8 & E8, E9, E10 & $\begin{array}{l}\text { E8, E9, E10, E11, E12, E13, E14, E15, } \\
\text { E16, E17 }\end{array}$ & $\mathrm{E} 8, \mathrm{E} 9, \mathrm{E} 10$ & IV \\
\hline E9 & E8, E9, E10 & $\begin{array}{l}\text { E8, E9, E10, E11, E12, E13, E14, E15, } \\
\text { E16, E17 }\end{array}$ & $\mathrm{E} 8, \mathrm{E} 9, \mathrm{E} 10$ & IV \\
\hline E10 & E8, E9, E10 & $\begin{array}{l}\text { E8, E9, E10, E11, E12, E13, E14, E15, } \\
\text { E16, E17 }\end{array}$ & $\mathrm{E} 8, \mathrm{E} 9, \mathrm{E} 10$ & IV \\
\hline E11 & E8, E9, E10, E11 & E11, E13, E14, E17 & & \\
\hline E12 & E8, E9, E10, E12 & E12, E16, E17 & & \\
\hline E13 & E8, E9, E10, E11, E13, E14, E15 & E13, E17 & & \\
\hline E14 & E8, E9, E10, E11, E14 & E13, E14, E17 & & \\
\hline E15 & E8, E9, E10, E15 & E15, E17 & & \\
\hline E16 & E7, E8, E9, E10, E12, E16 & E16 & & \\
\hline E17 & E7, E8, E9, E10, E11, E12, E13, E14, E15, E17 & E17 & & \\
\hline
\end{tabular}

Table A6. Level V partition.

\begin{tabular}{cllcc}
\hline Element & \multicolumn{1}{c}{ Reachability Set } & \multicolumn{1}{c}{ Antecedent Set } & Intersection Set & Level \\
\hline E11 & E11 & E11, E13, E14, E17 & E11 & V \\
\hline E12 & E12 & E12, E16, E17 & V \\
\hline E13 & E11, E13, E14, E15 & E13, E17 & \\
\hline E14 & E11, E14 & E13, E14, E17 & E15 \\
\hline E15 & E15 & E15, E17 & V \\
\hline E16 & E12, E16 & E16 & \\
\hline
\end{tabular}

Table A7. Level VI partition.

\begin{tabular}{clllc}
\hline Element & Reachability Set & Antecedent Set & Intersection Set & Level \\
\hline E13 & E13, E14 & E13, E17 & & E14 \\
\hline E14 & E14 & E13, E14, E17 & E16 & VI \\
\hline E16 & E16 & E16 & & \\
\hline E17 & E13, E14, E17 & E17 & & \\
\hline
\end{tabular}


Table A8. Level VII partition.

\begin{tabular}{cllcc}
\hline Element & Reachability Set & Antecedent Set & Intersection Set & Level \\
\hline E13 & E13 & E13, E17 & E13 & VII \\
\hline E17 & E13, E17 & E17 & & \\
\hline
\end{tabular}

Table A9. Level VIII partition.

\begin{tabular}{ccccc}
\hline Element & Reachability Set & Antecedent Set & Intersection Set & Level \\
\hline E17 & E17 & E17 & E17 & VIII \\
\hline
\end{tabular}

\section{References}

1. World Bank Group. Poverty and Shared Prosperity 2016: Taking on Inequality; The World Bank: Herndon, VA, USA, 2016; p. 184.

2. Ravallion, M.; Chen, S. China's (uneven) progress against poverty. J. Dev. Econ. 2007, 82, 1-42. [CrossRef]

3. Montalvo, J.G.; Ravallion, M. The pattern of growth and poverty reduction in china. J. Comp. Econ. 2010, 38, 2-16. [CrossRef]

4. Yao, S. Agricultural Reforms and Grain Production in China; Springer: London, UK, 2016.

5. OECD. Agricultural Policies in China after WTO Accession; OECD: Paris, France, 2002.

6. Chen, H.T. Unique rural industry and urbanization in the original rural area: Interactive relations and realization paths. J. Fujian Agric. For. Univ. (Philos. Soc. Sci.) 2016, 5, 29-33. [CrossRef]

7. Yang, H.F. On the development of local agricultural specialty industrybased on the theory of porter's"diamond"model (PDM): Taking Jiaxing snail industry as an example. Issues Agric. Econ. 2017, 3, 96-101. [CrossRef]

8. Li, Y.; Su, B.; Liu, Y. Realizing targeted poverty alleviation in china. China Agric. Econ. Rev. 2016, 8, 443-454. [CrossRef]

9. Jalan, J.; Ravallion, M. Determinants of Transient and Chronic Poverty: Evidence from Rural China; World Bank Publications: Washington, DC, USA, 1998.

10. Sun, Z.G.; Zhong, R.G.; Liu, Z.Y.; Wang, S.T.; Zhang, M.; Xiong, W.Z.; Huang, L.M. Geographical indication protection of specialty resources in Wuling mountains area and supporting strategies for characteristic industry. Shandong Agric. Sci. 2012, 12, 37.

11. Thirtle, C.; Lin, L.; Piesse, J. The impact of research-led agricultural productivity growth on poverty reduction in Africa, Asia and Latin America. World Dev. 2003, 31, 1959-1975. [CrossRef]

12. De Janvry, A.; Sadoulet, E. Agricultural growth and poverty reduction: Additional evidence. World Bank Res. Obs. 2009, 25, 1-20. [CrossRef]

13. Fan, J.; Li, P. The scientific foundation of major function oriented zoning in china. J. Geogr. Sci. 2009, 19, 515. [CrossRef]

14. Jia, J.; Qin, C.; Liu, Y. Do community-based development projects alleviate poverty? Evidence from rural china. International Center for Public Policy Working Paper Series, at AYSPS, GSU paper1722, International Center for Public Policy, Andrew Young School of Policy Studies, Georgia State University. 2017. Available online: https:/ /ideas.repec.org/p/ays/ispwps/paper1722.html (accessed on 12 March 2018).

15. Ghazala, M.; Rao, V. Community-based and -driven development: A critical review. World Bank Res. Obs. 2004, 19, 1-39.

16. Chambers, R. The origins and practice of participatory rural appraisal. World Dev. 1994, 22, $953-969$. [CrossRef]

17. Cornwall, A. Historical perspectives on participation in development. Commonw. Comp. Politics 2006, 44, 62-83. [CrossRef]

18. Bond, P. Global governance campaigning and MDGs: From top-down to bottom-up anti-poverty work. Third World Quart. 2006, 27, 339-354. [CrossRef]

19. Chakrabarti, A.; Dhar, A. Social funds, poverty management and subjectification: Beyond the World Bank approach. Camb. J. Econ. 2013, 37, 1035-1055. [CrossRef] 
20. Khang, D.B.; Moe, T.L. Success criteria and factors for international development projects: A life-cycle-based framework. Proj. Manag. J. 2008, 39, 72-84. [CrossRef]

21. Dongier, P.; Van Domelen, J.; Ostrom, E.; Ryan, A.; Wakeman, W.; Bebbington, A.; Alkire, S.; Esmail, T.; Polski, M. Community Driven Development. World Bank Poverty Reduction Strategy Paper; World Bank: Washington, DC, USA, 2003.

22. David, R.M.; Victoria, A.B. Community-based planning and poverty alleviation in Oaxaca, Mexico. J. Plan. Educ. Res. 2008, 27, 245-260. [CrossRef]

23. Pretty, J.N. Participatory learning for sustainable agriculture. World Dev. 1995, 23, 1247-1263. [CrossRef]

24. White, A.T.; Christie, P.; D'Agnes, H.; Lowry, K.; Milne, N. Designing ICM projects for sustainability: Lessons from the Philippines and Indonesia. Ocean Coast. Manag. 2005, 48, 271-296. [CrossRef]

25. Chantarat, S.; Barrett, C.B. Social network capital, economic mobility and poverty traps. J. Econ. Inequal. 2012, 10, 299-342. [CrossRef]

26. Shuai, C.M.; Gong, B.; Zhang, L. Anti-poverty project sustainability in rural china: An empirical analysis. Outlook Agric. 2012, 41, 153-161. [CrossRef]

27. Yalegama, S.; Chileshe, N.; Ma, T. Critical success factors for community-driven development projects: A Sri Lankan community perspective. Int. J. Proj. Manag. 2016, 34, 643-659. [CrossRef]

28. Beard, V.A. Household contributions to community development in Indonesia. World Dev. 2007, 35, 607-625. [CrossRef]

29. Li, Y.; Liu, Y.; Long, H.; Cui, W. Community-based rural residential land consolidation and allocation can help to revitalize hollowed villages in traditional agricultural areas of china: Evidence from Dancheng county, Henan province. Land Use Policy 2014, 39, 188-198. [CrossRef]

30. Hu, Y.B.; Liu, C.S.; Huang, Y.J.; Wang, P.Q. A research on how to learn and adopt NGO intervention model against poverty in the action of poverty alleviation in new phase-Taking Kunming for example. China For. Econ. 2015, 135, 11-15. [CrossRef]

31. $\mathrm{Xu}, \mathrm{H} . ; \mathrm{Li}, \mathrm{X}$. Operating difficulties and explanations of industry poverty alleviation projects under the accurate poverty alleviation perspective-With greenhouse vegetable project in Licun village in north china as an example. J. Northwest A F Univ. (Soc. Sci. Ed.) 2017, 1, 002.

32. Platteau, J.-P.; Abraham, A. Participatory development in the presence of endogenous community imperfections. J. Dev. Stud. 2002, 39, 104-136. [CrossRef]

33. Dasgupta, A.; Beard, V.A. Community driven development, collective action and elite capture in Indonesia. Dev. Chang. 2007, 38, 229-249. [CrossRef]

34. Iversen, V.; Chhetry, B.; Francis, P.; Gurung, M.; Kafle, G.; Pain, A.; Seeley, J. High value forests, hidden economies and elite capture: Evidence from forest user groups in Nepal's Terai. Ecol. Econ. 2006, 58, 93-107. [CrossRef]

35. Li, Y.H.; Wang, Y.F.; Liu, Y.S. Impact and mechanism of social capital in poverty alleviation of china. Bull. Chin. Acad. Sci. 2016, 31, 302-308.

36. Manwa, H.; Manwa, F. Poverty alleviation through pro-poor tourism: The role of Botswana forest reserves. Sustainability 2014, 6, 5697. [CrossRef]

37. Hussain, I. Pro-poor intervention strategies in irrigated agriculture in Asia: Issues, lessons, options and guidelines. Irrig. Drain. 2007, 56, 119-126. [CrossRef]

38. Wang, S. Reducing poverty through agricultural development in china. IDS Bull. 2013, 44, 55-62. [CrossRef]

39. Bai, L.; Zhao, B.-H. Research on the choice of industrialization poverty alleviation mode and benefit mechanism-Based on case analysis of mushroom industry of Yi county in Hebei. Hebei Acad. J. 2015, 4,30 .

40. Bolwig, S.; Ponte, S.; Du Toit, A.; Riisgaard, L.; Halberg, N. Integrating poverty and environmental concerns into value-chain analysis: A conceptual framework. Dev. Policy Rev. 2010, 28, 173-194. [CrossRef]

41. Riisgaard, L.; Bolwig, S.; Ponte, S.; Du Toit, A.; Halberg, N.; Matose, F. Integrating poverty and environmental concerns into value-chain analysis: A strategic framework and practical guide. Dev. Policy Rev. 2010, 28, 195-216. [CrossRef]

42. Yang, G.T.; Shang, Y.J. Discussion on industrialization poverty alleviation model in china's rural areas. Rural Econ. 2009, 9, 48-51. [CrossRef]

43. Donovan, J.; Poole, N. Changing asset endowments and smallholder participation in higher value markets: Evidence from certified coffee producers in Nicaragua. Food Policy 2014, 44, 1-13. [CrossRef] 
44. Carney, D. Approaches to Sustainable Livelihoods for the Rural Poor; Overseas Development Institute: London, UK, 1999.

45. Shuai, C.; Li, Z.; Sun, R. IFAD projects: Results and impact on poverty reduction in rural china. Outlook Agric. 2011, 40, 329-336. [CrossRef]

46. Dorward, A.; Kydd, J.; Morrison, J.; Urey, I. A policy agenda for pro-poor agricultural growth. World Dev. 2004, 32, 73-89. [CrossRef]

47. Stoian, D.; Donovan, J.; Fisk, J.; Muldoon, M.F. Value chain development for rural poverty reduction: A reality check and a warning. Enterp. Dev. Microfinanc. 2012, 23, 75-92. [CrossRef]

48. Christensen, B.C.; Kenney, M.; Patton, D. Regional identity can add value to agricultural products. Calif. Agric. 2015, 69, 85-91. [CrossRef]

49. Xing, X.Y.; Hu, J.; Liang, S.; Tian, F.; Li, J.F. Research of agricultural products brand implementation strategy in poverty-stricken counties around the capital. Tianjin Agric. Sci. 2014, 20, 112-115. [CrossRef]

50. Li, S.C.; Zhong, W.Z. An analysis of the approaches to support the rural finance for developing agricultural industrialization-Focusing on the Gannan navel orange. J. Jiangxi Norm. Univ. (Philos. Soc. Sci. Ed.) 2014, 2, $41-45$.

51. Attri, R.; Dev, N.; Sharma, V. Interpretive structural modelling (ISM) approach: An overview. Res. J. Manag. Sci. 2013, 2319, 1171.

52. Ravi, V.; Shankar, R. Analysis of interactions among the barriers of reverse logistics. Technol. Forecast. Soc. Chang. 2005, 72, 1011-1029. [CrossRef]

53. Dubey, R.; Gunasekaran, A.; Chakrabarty, A. Ubiquitous manufacturing: Overview, framework and further research directions. Int. J. Comput. Integr. Manuf. 2017, 30, 381-394. [CrossRef]

54. Dubey, R.; Ali, S.S. Identification of flexible manufacturing system dimensions and their interrelationship using total interpretive structural modelling and fuzzy Micmac analysis. Glob. J. Flex. Syst. Manag. 2014, 15, 131-143. [CrossRef]

55. Shen, L.; Song, X.; Wu, Y.; Liao, S.; Zhang, X. Interpretive structural modeling based factor analysis on the implementation of emission trading system in the Chinese building sector. J. Clean. Prod. 2016, 127, $214-227$. [CrossRef]

56. Malone, D.W. An introduction to the application of interpretive structural modeling. Proc. IEEE 1975, 63, 397-404. [CrossRef]

57. Sushil, S. Interpreting the interpretive structural model. Glob. J. Flex. Syst. Manag. 2012, 13, 87-106. [CrossRef]

58. Duperrin, J.; Godet, M. Methode de hierarchisation des elements d'un systeme. Rapp. Econ. CEA 1973, 1, 49-51.

59. Sharma, H.; Gupta, A. The objectives of waste management in India: A futures inquiry. Technol. Forecast. Soc. Chang. 1995, 48, 285-309. [CrossRef]

60. Liu, Y.S.; Zhou, Y.; Liu, J.L. Regional differentiation characteristics of rural poverty and targeted poverty alleviation strategy in China. Bull. Chin. Acad. Sci. 2016, 31, 269-278.

61. Maertens, M.; Swinnen, J.F.M. Trade, standards, and poverty: Evidence from Senegal. World Dev. 2009, 37, 161-178. [CrossRef]

62. Ponte, S. Governing through quality: Conventions and supply relations in the value Chain for South African wine. Sociol. Rural. 2009, 49, 236-257. [CrossRef]

63. Ponte, S.; Gibbon, P. Quality standards, conventions and the governance of global value chains. Econ. Soc. 2005, 34, 1-31. [CrossRef]

64. Akanbi, O.A. Structural and institutional determinants of poverty in sub-Saharan African countries. J. Hum. Dev. Capabilities 2015, 16, 122-141. [CrossRef]

65. Srinivas, S.; Dani, J.B.; Stephen, G.S. Markets and marketing research on poverty and its alleviation: Summarizing an evolving logic toward human capabilities, well-being goals and transformation. Market. Theory 2017, 17, 323-340. [CrossRef]

66. Key, N.; Runsten, D. Contract farming, smallholders, and rural development in Latin America: The organization of agroprocessing firms and the scale of outgrower production. World Dev. 1999, 27, 381-401. [CrossRef] 
67. Tapela, B.N. Livelihoods in the wake of agricultural commercialisation in South Africa's poverty nodes: Insights from small-scale irrigation schemes in Limpopo province. Dev. South. Afr. 2008, 25, 181-198. [CrossRef]

68. Ito, J.; Bao, Z.; Su, Q. Distributional effects of agricultural cooperatives in china: Exclusion of smallholders and potential gains on participation. Food Policy 2012, 37, 700-709. [CrossRef]

69. Michelini, J.J. Small farmers and social capital in development projects: Lessons from failures in Argentina's rural periphery. J. Rural Stud. 2013, 30, 99-109. [CrossRef]

70. Wiesinger, G. The importance of social capital in rural development, networking and decision-making in rural areas. Rev. Géogr. Alp. 2007, 2009, 43-56. [CrossRef]

71. Carter, M.R.; Barrett, C.B. The economics of poverty traps and persistent poverty: An asset-based approach. J. Dev. Stud. 2006, 42, 178-199. [CrossRef]

72. Leong, C.M.L.; Pan, S.-L.; Newell, S.; Cui, L. The emergence of self-organizing e-commerce ecosystems in remote villages of china: A tale of digital empowerment for rural development. Mis Quart. 2016, 40, 475-484. [CrossRef]

73. Chen, L.; Johnson, G.A.; Luo, Y. Great and Small Walls of China: Distance E Chinese e-Commerce; NET Institute Working Paper No. 15-14; NET Institute: Daytona Beach, FL, USA, 2015.

74. Fan, J.; Tang, L.; Zhu, W.; Zou, B. The Alibaba Effect: Spatial Consumption Inequality and the Welfare Gains from e-Commerce. 2016. Available online: http://dx.doi.org/10.2139/ssrn.2707293 (accessed on 12 March 2018).

75. Li, A.H. E-commerce and Taobao villages. A promise for china's rural development? China Perspect. 2017, 2017, 57-62.

76. Long, H.; Tu, S.; Ge, D. Effects of new-type urbanization on poverty alleviation and development and corresponding countermeasures. Bull. Chin. Acad. Sci. 2016, 31, 309-319.

77. Riisgaard, L.; Bolwig, S.; Matose, F.; Ponte, S.; Du Toit, A.; Halberg, N. A Strategic Framework and Toolbox for Action Research with Small Producers in Value Chains; DIIS Working Paper; Danish Institute for International Studies (DIIS): Copenhagen, Denmark, 2008.

(C) 2018 by the authors. Licensee MDPI, Basel, Switzerland. This article is an open access article distributed under the terms and conditions of the Creative Commons Attribution (CC BY) license (http:/ / creativecommons.org/licenses/by/4.0/). 